\title{
On the Campaign Trail(er): Deconstructing the Soundscape of the 2012 U.S. Presidential Election
}

\author{
DANA GORZELANY-MOSTAK AND JAMES DEAVILLE
}

\author{
Video 1: Soundscape Election 2012: The Trailer ${ }^{1}$ \\ View at: http://dx.doi.org/10.3998/mp.9460447.0009.201
}

The 2012 U.S. presidential election provided an opportunity for a team of scholars to undertake the first comprehensive study of music associated with a national political campaign. Already before the final selection of candidates in August/September, four academics had made plans to follow the musical path of the election battle as it unfolded, whatever the outcome in November. We divided the research tasks according to four major areas of musical deployment in recent presidential campaigns: music at the conventions (James Deaville), music in campaign advertisements (Joanna Love), user-generated, newly composed music on YouTube (Michael Saffle), and candidate and voter engagement with digital playlists (Dana Gorzelany-Mostak). The resulting four papers were presented in one session at the annual meeting of the Society for American Music (SAM) in March 2013 and then revised for publication in this forum.

We opened the SAM panel with the above trailer, which reflects certain affinities between the paratexts of the cinematic trailer and the paratexts of campaign music with regard to history, content, and function. ${ }^{2}$ In the present day, trailers precede the film as far as the public is concerned; they are a preview of coming attractions intended to cajole audiences into seeing and hearing their favorite celebrities, stories, or film genres on the big screen. However, when the cinema was in its infancy at the beginning of the twentieth century, trailers were exhibited at the end of the film rather than the beginning, which explains their designation. ${ }^{3}$ In many cases, the trailer was actually a teaser that hinted towards what was in store for the protagonist of a serial film's next chapter. But hype represents only one function of the trailer. In its desire to aid the war effort, a committee of the National Association of the Motion Picture Industry distributed trailers that advertised the sale of war bonds in 1917. While the silent trailers of this period tended to use standard cinematographic practices of the time and draw upon fairly obvious advertising tactics (including photoplay music in theaters), by the 1930s, sophisticated graphics and special effects, underscoring, and narration became commonplace as trailers were offered as transitional shorts between the multiple sound films screened on a given day. ${ }^{4}$

\footnotetext{
${ }^{1}$ We wish to extend our special thanks to Meghan Goodchild (McGill University) for editing this trailer.

${ }^{2}$ Regarding paratexts, see above all Gérard Genette, Seuils (Paris: Éditions du Seuil, 1987).

${ }^{3}$ Lisa Kernan, Coming Attractions: Reading American Movie Trailers (Austin: University of Texas Press, 2004), 25. For resources that address the sound design of film trailers, see James Deaville's interdisciplinary project "Trailaurality," http://www.trailaurality.com.

4 "Why Are They Called 'Trailers' If They're Shown Before the Movie?" The Straight Dope, November 6, 2007, http://www.straightdope.com/columns/read/2270/why-are-they-called-trailers-if-theyre-shown-em-before-em-the-movie. See "Film Flashes," New York Times, June 3, 1917. "The movies are doing their bit to make the Liberty Loan a success. There are 
As the articles in this issue illustrate, the trailer's vocabulary-celebrity, teaser, hype, sophisticated graphics, special effects, underscoring, and blockbuster-can readily be applied to any discussions regarding the 2012 presidential campaign, which might be accurately framed as a prolonged series of media spectacles, in the sense of Guy Debord. ${ }^{5}$ And like the trailer, campaign music can be entertainment, advertisement, or politics, but in the overwhelming number of cases we investigate in our studies, it is a complex amalgamation of all three. Around the same time that the trailer came into existence, the sounds of a local brass band and a small cadre of singers may have welcomed a candidate to the stage (or stump) with an impromptu performance of a campaign song set to a popular tune of the day. Songsters that included newly penned lyrics praising the candidate's character may have circulated among his throngs of supporters. But with regard to campaign music in the twenty-first century, campaign songs only provide us a limited slice of what can be described as a vast, diverse, and dynamic soundscape. Like the trailer, campaign music has incorporated new technologies to foster its promotional functions. In our respective articles, we use the term "campaign music" as a catch-all appellation that can refer not only to a candidate's official campaign song (or songs) but also to an inconspicuous melody heard in the background of a campaign advertisement, a performance of an activist-artist at a political convention or rally, a newly composed song created to lionize or denigrate a political hopeful, a mashup including musicalized snippets of material from a candidate's speeches, or even a candidate's online playlist. The media spectacle, be it a trailer or a political campaign, is a multisensory affair in which music plays a leading, yet heretofore underobserved role.

The clips included in Soundscape Election 2012: The Trailer highlight five interrelated aspects of the campaign soundscape that are relevant to each of our articles. The first, the fluid boundary between political culture and popular culture, is perhaps best illustrated by the Romney- and Obama-themed "Gangnam Style" parodies that bookend the trailer. ${ }^{6}$ With these music videos, the creative minds at CollegeHumor and writer/performer Eric Schwartz, respectively, appropriate the visual style and musical rhetoric of Korean rapper Psy's summer 2012 K-pop hit while masterfully engaging with the media's characterization of the two candidates. The Romney "Gangnam," sung from the first-person perspective of a spot-on Romney impersonator (Matt Walton), engages with the class-based critique of Psy's original. The visual tropes of both, heavily reliant on hyperbole and the mixing of class signifiers, playfully mock those who explicitly perform their elevated socioeconomic status. CollegeHumor recasts Psy's jab at Korean consumer fetishism as a critique of Romney's conspicuous consumption and points towards the contrivance of such displays. Although the opening close-up appears to show Psy lounging carefree on a tropical beach, the succeeding wide-angle shot reveals his location to be a children's playground, a decidedly mundane, bourgeois locale (Fig. 1a). The Romney parody opens with a similar sandy backdrop, only later revealing the beach to be a sand trap. While the signifiers of old money abound-crystal flutes and champagne, argyle sweaters, polo horses, and suits in shades of gray-an oblivious Romney appears enclosed in the

approximately 15,000 movie theatres in the country, and in each of these during the next two weeks at every performance there will be flashed on the screen the suggestion that everybody buy a bond. Slides and film trailers have been sent to every theatre, and it is estimated that 15,000,000 people will thus be reached, as that is the number the movie men calculated attend their theatres every week. More and more the motion-picture screen is being recognized as a medium of disseminating information."

${ }^{5}$ Guy Debord, La Société du spectacle (Paris: Buchet-Chastel, 1967).

6 “'Mitt Romney Style' ('Gangnam Style' Parody),” directed by Vincent Peone, produced by Jon Wolf, written by Adam Conover and Emily Axford, October 8, 2012, video clip, YouTube, http://www.youtube.com/watch?v=yTCRwi71 ns; “Obama Style (PSY 'Gangnam Style' Parody) Feat. Smooth-E and Alphacat,” September 21, 2012, video clip, YouTube, http://www.youtube.com/watch?v=Xwh8kWuire8. 
least desirable location of the well-manicured golf course (Fig. 1b). Addressing an Ann Romney impersonator in a later frame, the candidate exclaims, "Bitch it's Friday night you know we benefit hoppin'," and then follows up with pelvic thrusts while inveigling a table of formally dressed dinner guests to "check [his] conspicuous consumption" (Fig. 1c). The spaces featured in the clip-the putting green, the horse stable, and the elegant benefit dinner-affirm his status, but his ungainly use of obscene gestures, a delivery style associated with the black cultural practice called "boasting," and vernacular dialect, all highlight the suspect nature of his public persona.

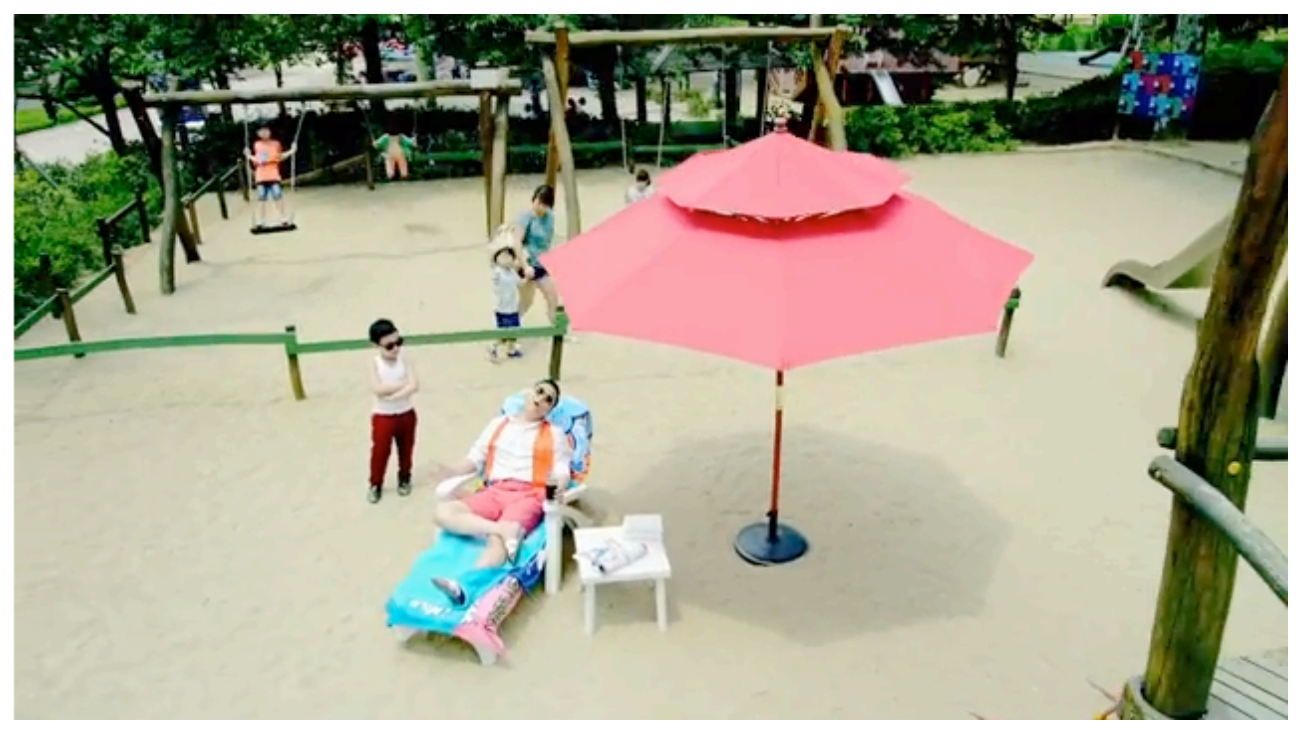

Figure 1a: Psy lounges on a playground in "Gangnam Style"

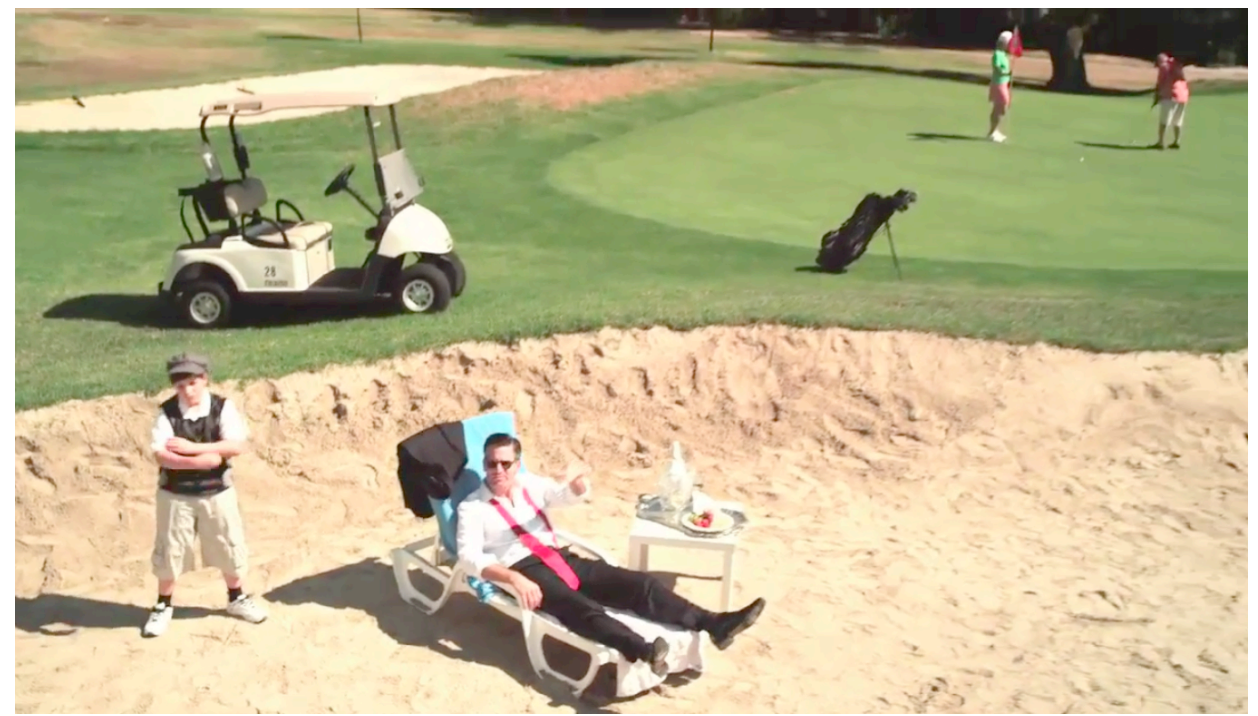

Figure 1b: Mitt Romney lounges on a sand trap in "Mitt Romney Style" 


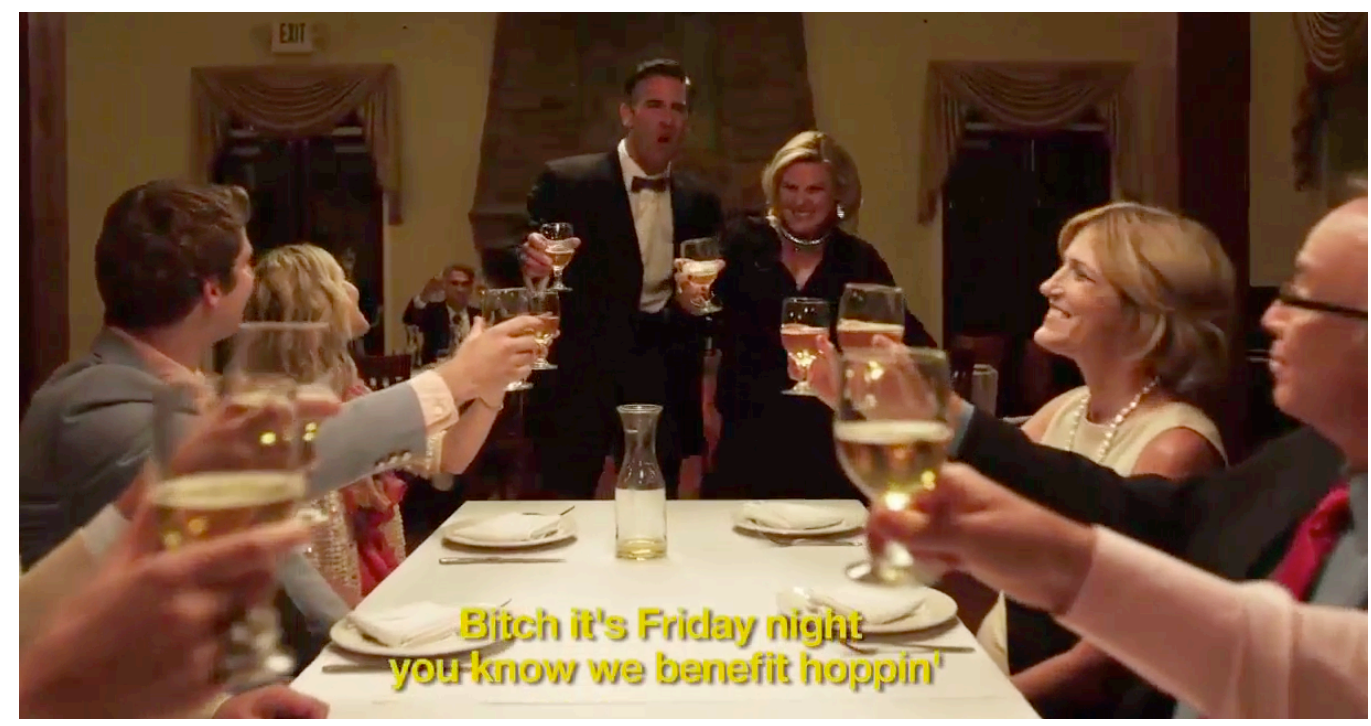

Figure 1c: Mitt and Ann Romney "benefit hoppin"” in "Mitt Romney Style”

Similar to "Mitt Romney Style," the "Obama Style" parody relies on current election narratives as a point of departure, but the tone comes across as less partisan. In the opening frames, an Obama impersonator (with pitch-perfect Obama-style cadences) claims "someone helped [Psy] build" the "new song and dance that is takin' the world by storm." With his imagined Psy success anecdote, the impersonator references the controversial remarks the real Democratic candidate made in a speech where he espoused the viewpoint that affluent people earned their wealth only because the "unbelievable American system" allowed them to do so. ${ }^{7}$ Sung from the perspective of a citizen rather than the candidate himself, the video works to demystify Obama's popularity to a certain extent. While the lyrics and visual imagery matter-of-factly reference his superstar status, relationships with celebrities like Oprah Winfrey and George Clooney, and ability to create an "awesome" campaign poster, they also hint towards the perceived failures of the incumbent's first term. And like other musical offerings we consider in our respective articles, the Obama "Gangnam" turns its critical eye towards the voters as well: the singing citizen ponders whether or not the candidate's legion of fans will actually turn up at the polls on election day. "Mitt Romney Style" received 34.6 million views on YouTube alone, and satirical and parodic videos of the two frontrunners sometimes garnered more views than the debates and conventions on television. ${ }^{8}$

The advertisement "Wake the Fuck Up!" featuring Samuel L. Jackson, the most remixed and mashed-up actor in cyberspace, takes the same stance in its parody of the (adults-only) bedtime story Go the $F^{\star \star} k$ to Sleep (2011). ${ }^{9}$ Here, various musical styles are deployed to advance the narrative arc of the

\footnotetext{
${ }^{7}$ The Obama impersonator's remarks in "Obama Style": "Now let's say you're a Korean pop star, and you have a new song and dance that is takin' the world by storm. It's important for everyone to know that you didn't build that. Someone helped you build it. And today, I'm going to show you exactly ... me." The real Obama's remarks: "If you were successful, somebody along the line gave you some help. There was a great teacher somewhere in your life. Somebody helped to create this unbelievable American system that we have that allowed you to thrive. Somebody invested in roads and bridges. If you've got a business - you didn't build that. Somebody else made that happen." See "Remarks by the President at a Campaign Event in Roanoke, Virginia" (press release), White House Office of the Press Secretary, Roanoke Fire Station \# 1, Roanoke, Virginia, July 13, 2012, http://www.whitehouse.gov/the-press-office/2012/07/13/remarks-president-campaign-event-roanoke-virginia. ${ }^{8}$ Jeffrey P. Jones, "Presidential Campaigns as Cultural Events: The Convergence of Politics and Popular Culture in Election 2012," in The 2012 Presidential Campaign: A Communication Perspective, ed. Robert E. Denton, Jr. (Lanham, MD: Rowman and Littlefield, 2013), 126.

${ }^{9}$ Aram Sinnreich, Mashed Up: Music, Technology, and the Rise of Configurable Culture (Amherst: University of Massachusetts
} 
advertisement. The most predominant element is a funk groove, likely a reference to Jackson's role in the 2000 sequel to the blaxploitation film Shaft (1971). It is Jackson's brashness and "street cred" that are harnessed to shake the potential voter out of his or her apathy. ${ }^{10}$ Developed by the Jewish Council for Education \& Research (a Super PAC), this advertisement demonstrates how online forums have expanded the range of creative possibilities for organizations that wish to appropriate and recontextualize the sometimes-irreverent icons and artifacts of popular culture in order to galvanize their supporters. ${ }^{11}$

Political parodies like this one have historically served as vehicles for social critique in a wide variety of mediated contexts; however, in recent years there has been an uptick in the circulation of these texts due to the rise of user-generated content sites, hybrid political entertainment talk shows such as Politically Incorrect (with Bill Maher), and fake news programs such as The Daily Show with Jon Stewart. ${ }^{12}$ In 2012 Romney's wealth (his refusal to release his tax records and the "corporations are people" and "47 percent" remarks) became fodder for purveyors of parody-comedians, talk show hosts, and even creators of campaign-inspired playlists and YouTube videos. As Gorzelany-Mostak shows, this topic functioned as the linchpin for voters "recommending" playlists for the Republican candidate. But this conceit extends beyond Romney. One video Saffle analyzes, "O.P.M.” ("Other People's Money”), subjects both candidates to derision for disregarding the nation's financial solvency. While some online parody offerings directly engaged with campaign narratives, others set politics aside in favor of nonpartisan laughs and merriment. Obama's speeches remixed and transformed into Carly Rae Jepsen's "Call Me Maybe" (a song that rivaled Psy's in popularity in 2012) certainly can be placed in this category. ${ }^{13}$

The circulation of the above cited compositions also demonstrates the second aspect of campaign music that we wish to highlight: the transformative role of social media, which have carved out a virtual space where the digital citizen can more fully engage with the candidate and his or her music. To a certain degree, American citizens have always participated in the creation of the campaign soundscape; however, as Henry Jenkins states, "Media convergence fosters a new participatory folk culture by giving average people the tools to archive, annotate, appropriate and recirculate content." ${ }^{14}$ Referring to the 2008 campaign, political scientist Dewey M. Clayton claimed Barack Obama "attracted many more artists to create unsolicited music and music videos than any other candidate in American political history." ${ }^{15}$ The

\footnotetext{
Press, 2010), 79.

${ }^{10}$ We would like to acknowledge Joanna Love for providing the analysis of this clip.

11 "Samuel L. Jackson Short Film Ad: Wake the Fuck Up !!! For Obama 2012" (advertisement from the Jewish Council for Education and Research), video clip, YouTube, http://2012.talkingpointsmemo.com/2012/10/jcer-sarah-silverman-samueljackson-wake-the-f-up.php. Jackson recorded an audio version of the book in 2011.

${ }^{12}$ For more on satire and parody as modes of political communication, see Jeffrey P. Jones, "Parody, Performativity, and Play: The Reinvigoration of Citizenship through Political Satire," in A Companion to New Media Dynamics, ed. John Hartley, Jean Burgess and Axel Bruns (Malden, MA: Wiley-Blackwell, 2013), 396-406; and Dannagal G. Young, R. Lance Holbert, and Kathleen Hall Jamieson, "Successful Practices for the Strategic Use of Political Parody and Satire: Lessons From the P6 Symposium and the 2012 Election Campaign," American Behavioral Scientist 58, no. 9 (2014): 1111-130. For more on parody campaign songs, see Irwin Silber, Songs America Voted By: With the Words and Music That Won and Lost Elections and Influenced the Democratic Process (Harrisburg, PA: Stackpole, 1971); Janet I. Nicoll and G. Douglas Nicoll, "Political Campaign Songs from Tippecanoe to '72," Popular Music and Society 1, no. 4 (1972): 193-209; Jodi Larson, "American Tune: Postwar Campaign Songs in a Changing Nation," Fournal of Popular Culture 42, no. 1 (2009): 3-26; and Benjamin S. Schoening and Eric T. Kasper, Don't Stop Thinking about the Music: The Politics of Songs and Musicians in Presidential Campaigns (Lanham, MD: Lexington, 2012).

${ }^{13}$ The video was released June 4, 2012 on "Barack's Dubs," a YouTube channel created by Fadi Saleh. "Barack Obama Singing 'Call Me Maybe' by Carly Rae Jepsen,” produced by Fadi Saleh, June 4, 2012, video clip, YouTube, http://www.youtube.com/watch?v=hX1YVzdnpEc.

${ }^{14}$ Henry Jenkins, “Convergence? I Diverge.” Technology Review 104, no. 5 (2001): 93.

${ }^{15}$ Dewey M. Clayton, The Presidential Campaign of Barack Obama: A Critical Analysis of a Racially Transcendent Strategy (New York: Routledge, 2010), 144.
} 
countless homage videos, parodies, newly composed campaign songs, and mixtapes on YouTube alone substantiate Clayton's claim. Such activity dwindled in 2012, but the site continued to serve as a forum for the expression of political discontent as manifest in song. The user-generated composition we include in the trailer, "They'll Do Anything," written and performed by "average citizen" Michael McRae, best exemplifies this trend. ${ }^{16}$

As Saffle posits in his article, McRae's folk-inspired, nonpartisan jab directed at the campaign apparatus also brings into focus the ways in which the generic and stylistic connotations of popular music can be made to signify for candidates, parties, and specific ideological orientations. We see this at work in live contexts as well, and here is where the third aspect-music's role in candidate image-buildingprominently comes into play. Rarely do politicians or high-profile speakers take the stage at political rallies or conventions without a bit of entrance music, as is clear from Deaville's tables. The trailer shows Michelle Obama taking the stage at the Democratic National Convention to the strains of Stevie Wonder's "Signed, Sealed, Delivered I'm Yours," a song that frequently punctuated Obama's 2008 speeches on the campaign trail. ${ }^{17}$ In addition to reminding delegates of the energy and optimism generated by his earlier campaign, the '70s R\&B classic offers connotations of racial uplift, perseverance, and equality as articulated by an iconic figure in black music (and Obama endorser). But the connections run deeper. The president and first lady have, on numerous occasions, noted the role Wonder's music has played in their lives: Barack Obama demonstrated his knowledge of Wonder's oeuvre in a 2008 Rolling Stone interview, and several news outlets cited Wonder's song "You and I" as the Obamas' wedding song. ${ }^{18}$ In presenting Wonder with the Gershwin Prize in 2009, Obama stated, "I think it's fair to say that had I not been a Stevie Wonder fan, Michelle might not have dated me. We might not have married. The fact that we agreed on Stevie was part of the essence of our courtship." 19 The use of "Signed, Sealed, Delivered I'm Yours" as entrance music for Mrs. Obama serves as a biographical retrospective of sorts for both the political and personal histories of the Obamas while (re-)establishing the candidate's connection with the ethos of Motown and the values of the Civil Rights period. And positioning this in relation to the cinematic trailer, we could argue that entrance music in general functions as a teaser of sorts to lure the audience in and prepare them for a political speech that engages with the same themes, whatever the party and style.

While entrance and exit songs, playlists established for rallies, or even a candidate's own divulgence of musical tastes might allow him or her to connect with a certain community, display cultural competence, or articulate a specific worldview, these things can also be harnessed by the opposition in order to undercut that person's image. This is to say, advertisements may deploy popular music signifiers in a way that casts a negative light on certain aspects of a candidate's image. In her analysis of campaign advertisements, including Super PAC American Crossroads' "Cool," Love shows how "hokey music" was

\footnotetext{
16 “They'll Do Anything - 2012 Election Song," composed and performed by Michael McRae, June 30, 2012, video clip, YouTube, http://www.youtube.com/watch?v=kITdzGP3O1c.

17 "Michelle Obama DNC Speech 2012 Complete: 'How Hard You Work' More Important than Income," September 4, 2012, video clip, YouTube, http://www.youtube.com/watch?v=IVGAI805i4o.

${ }^{18}$ Obama's remarks: "When I was just at that point when you start getting involved with music, Stevie had that run with Music of My Mind, Talking Book, Fulfillingness' First Finale, and Innervisions, and then Songs in the Key of Life. Those are as brilliant a set of five albums as we've ever seen." See Jann S. Wenner, “A Conversation with Barack Obama," Rolling Stone, July 10-24, 2008, http://www.jannswenner.com/Archives/Barack_Obama.aspx. Innervisions (1973) actually predated Fulfillingness' First Finale (1974). People magazine's website cited Stevie Wonder's "You and I" as the Obamas' first-dance song at their wedding. See Julie Wang, ed., "Michelle Obama Biography,” People, accessed March 26, 2015, http://www.people.com/people/michelle obama/biography.

${ }^{19}$ See “Obamas Praise Stevie Wonder at White House," CNN, February 26, 2009, http://www.cnn.com/2009/SHOWBIZ/Music/02/26/stevie.wonder.obama.
} 
deployed to paint Obama's preoccupation with pop culture as a liability rather than an asset. Advertisements and music parodies may not result in party hopping or motivate the politically inert to rush to the polls, but their hype can function as a form of social currency for candidates, and also for voters as they share, "like," or debate the music and/or images in various online forums. ${ }^{20}$

But voters are not the only citizens using social media to their advantage. They now expect candidates to mobilize social media, and their degree of competence with YouTube, Facebook, Twitter and the like has taken on electoral ramifications-the deployment of music in these contexts can range from music videos to subtle underscoring. These audiovisual forums have increasingly provided platforms through which candidates can engage voters with their music. Shortly after Obama sang a few bars of Al Green's "Let's Stay Together" at a 2012 Apollo Theater appearance, he shared a video link of his "Al debut" with followers on Tumblr. ${ }^{21}$ The candidate also used this forum to generate hype over his Spotify playlist, the contents of which became a subject for lively deliberation and debate. Thus, musical style is a political issue. At the same time, journalists and online commenters mapped discourses regarding music tastes onto broader campaign narratives assessing the candidates' authenticity and integrity, a phenomenon that Gorzelany-Mostak and Saffle address in their respective articles.

The pre-existing songs included on the candidates' online playlists or live rally lists are attached to artists with their own star personas that may be harnessed in order to further a political agenda. As Deaville shows in his article, this becomes especially apparent in the parties' selections of performers for the national conventions. This is the fourth aspect we address in our respective contributions: the function of music celebrity in presidential campaigning. As the trailer shows, the appearance of country-gospel quartet the Oak Ridge Boys, who prefaced their convention performance of "Amazing Grace" with a claim that we "need God more in our lives," reinforces the Republican Party's efforts to draw a parallel between Christian spirituality and patriotic devotion. At the same time, Joe Bonsall's comments and the song comprise a fairly obvious critique of the "godless" Democrats. ${ }^{22}$ The significance of place also comes into focus; for instance, at the 2012 Democratic National Convention in Charlotte, North Carolina, James Taylor, a longtime supporter of progressive causes, entertained delegates with a performance of the unofficial state anthem, "Carolina in My Mind." The conventions and rallies may have featured younger, more current acts, but the parties also solicited established artists, especially those who deal with nostalgic themes, whether it be old-time religion (the Oak Ridge Boys), the imagery of one's beloved childhood home (James Taylor), or, in the case of Bruce Springsteen (whose performance at an Obama rally is also included in the trailer), the values of the American heartland. ${ }^{23}$ And as Deaville notes, the hype surrounding the conventions' pre-released line-ups of artists itself functioned as cultural capital for the candidates.

\footnotetext{
20 “American Crossroads: 'Cool,” April 26, 2012, video clip, YouTube, http://www.huffingtonpost.com/2012/04/26/obamacelebrity-ad-american-crossroads-cool-video_n_1455413.html.

${ }^{21}$ Barack Obama Tumblr page, January 19, 2012, http://barackobama.tumblr.com/post/16157804624/think-progress-obamasings-he-sings-al. "Raw Video: Obama Sings Al Green,” January 20, 2012, video clip, YouTube, http://www.youtube.com/watch?v=y6uHR90Sq6k.

22 "The Oak Ridge Boys Sing 'Amazing Grace' at RNC," August 28, 2012, video clip, YouTube, http://www.youtube.com/watch?v=BbxZsa2RH_g.

23 “James Taylor's Full Performance at the DNC" ("Carolina in My Mind”), September 6, 2012, video clip, YouTube, http://www.youtube.com/watch?v=30fyy6paGsY; "Bruce Springsteen Joins Barack Obama on Final Day of Campaigning Video," November 6, 2012, video clip, Guardian, http://www.guardian.co.uk/world/video/2012/nov/06/bruce-springsteenbarack-obama-video.
} 
Although, in the absence of their former deliberative function, party conventions can indeed be considered "pseudo-events" as Deaville argues, they maintain their identities as media spectacles. Drawing on the work of Douglas Kellner, Love makes a similar argument with regards to the marketing of Obama as a media spectacle, which included the deployment of pop signifiers to establish the candidate's "celebrity coolness" in campaign advertisements. This is the fifth aspect of campaign music that our articles address: the role of music in the creation of media spectacles. While this term privileges the visual, music unquestionably plays a significant role in generating the spectacle of party conventions and any other largescale campaign event considered media-worthy. Celebrity appearances contribute to generating the spectacle within the walls of the convention center, but as Deaville notes, the lively protests that work to persuade and mobilize outside of the convention proper participate in the spectacle as well. Taking up the "evil corporations" and "irresponsible spending" tropes as his subjects, one singer outside the Republican National Convention disputed Romney's "corporations are people” remarks among a swarm of signs and slogans. ${ }^{24}$ While some protesters performed original songs for onlookers, others participated in impromptu chants and group singing, as illustrated by the protest outside the Democratic National Convention that we have included in the trailer. ${ }^{25}$ As is the case with the summer blockbuster film, much of the hype and commentary surrounding the spectacle is generated outside of the "official" space. The street functions as an unregulated, unscripted locus for deliberative debate and political expression, a good deal of it occurring through music and sound. But there is a commonality between the inner and outer spaces of these quadrennial rituals. Participants both inside and out mirror the screen-dominated cyclorama of the convention center; camera shots reveal everyone is holding a tiny screen of their own. As Saffle's article shows, screens are the primary conduit for campaign music in the twenty-first century, whether it be the underscore of a television advertisement, a candidate singing "America the Beautiful" on the trail, a parody on YouTube, or footage of an artist performing at a campaign rally (Fig. 2).

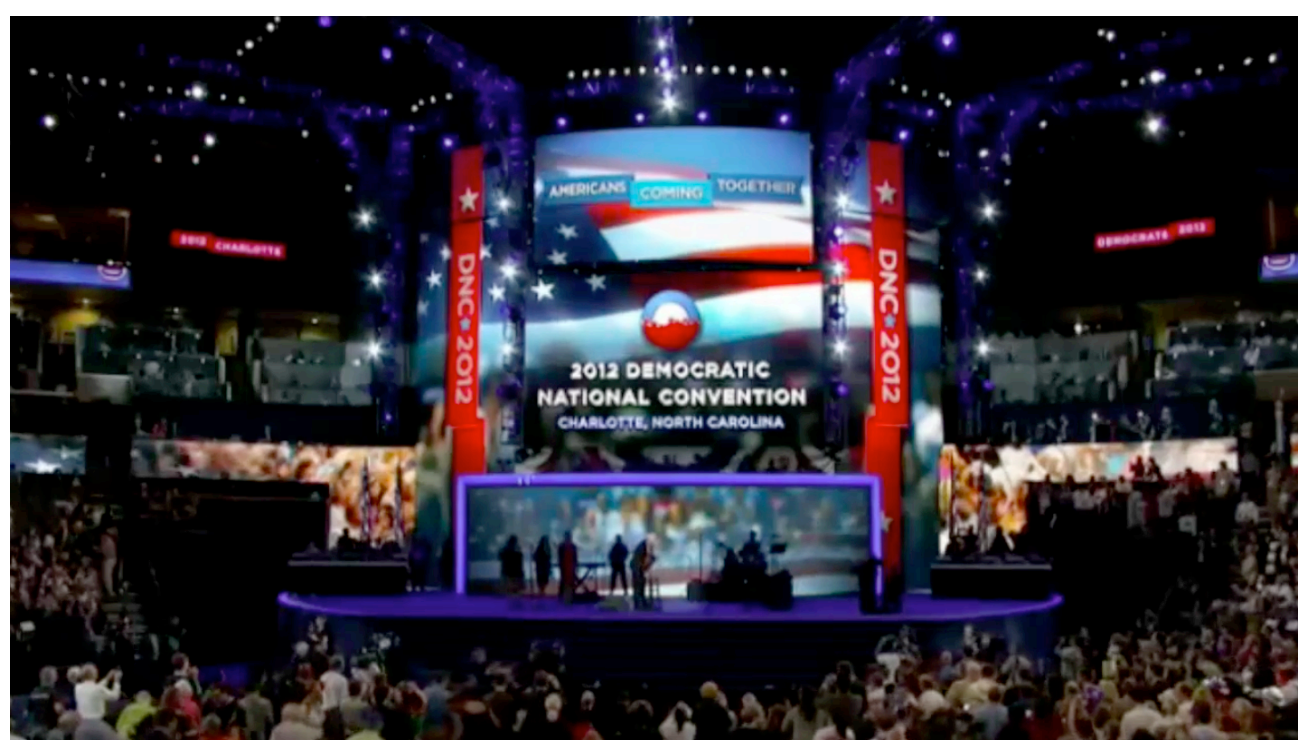

Figure 2: The 2012 Democratic National Convention

\footnotetext{
24 "RNC Protests," accessed June 30, 2013, video clip, YouTube, http://www.youtube.com/watch?v=Jw_txuweBsA (no longer available).

25 “Occupy Wall Street Protesters Flood Streets During DNC 2012,” September 6, 2012, video clip, YouTube, http://www.youtube.com/watch?v=GeKkTVA9uW0.
} 


\section{Conclusions}

In all of these aspects of the 2012 presidential campaign, music was a complicit partner, persuading, affirming, disturbing, even entertaining voters. That at times music served as a unheard yet active partner, a subliminal agent, makes this research all the more urgent. Just as in the film trailer, it all boils down to convincing people of a product worthy of their support, in the one case resulting in cinema attendance, in the other, a vote for a candidate. However, the parallels between the two cultural practices are not limited to their shared rhetorical appeal to consumers. Closer scrutiny uncovers mutual devices, practices, and strategies deployed to persuade the public to choose a particular commodity. The recognizable tropes of the film genre or stylistic musical markers shape these stories and enable the studio or party to tap into the personal identity of the target audience (the use of the same term "campaign" for advertising a market commodity-including a film—and a candidate is significant).

The visual and aural appeal of movie stars in trailers (usually dependent on the amount of exposure in the preview) and music celebrity endorsements and performances in campaign contexts offer audiences another point of identification. While stars generate economic capital and can act as intermediaries in order to "sell" the candidate to specific constituencies, they also model for potential voters modes of political engagement; or, to use Richard Dyer's words, "Stars represent typical ways of behaving, feeling, and thinking in contemporary society." ${ }^{26}$ Trailers and campaign music performances attach the commodity to celebrity, whereby that particular association transfers some of the star's or artist's power of recognition and appeal onto the product, enabling the celebrity to consecrate the film or candidate. ${ }^{27}$ When such endorsements misfire, as in the case of Clint Eastwood at the Republican National Convention, the results can be equally powerful in their destructiveness.

Trailers and campaign music likewise rely upon spectacle as a means of conveying their messages and hooking their publics. This introduction has already argued for the power of the spectacle above all in terms of mediatized representations and constructions of events (campaign stops, conventions, and even the protests at campaign events), candidates (here tie-ins with celebrity play a major role), and the process itself ("the election as spectacle"). And the political spectacle of the election relies upon music and sound for some of its most prominent effects and moments-be they iconic singing celebrities (or candidates taking up the microphone themselves), uplifting rally playlists, the clever musical parodies that "go viral," the "auricular" saturation of the convention soundscape through major live acts, frequent musical intros and outros, or even the extended cheering for the successful nominee at the conventions. Trailers similarly deploy music and sound in fashioning an unforgettable experience for the cinematic audience, which expects to be "blown away" through sight and sound.

And finally, trailers and campaign music share the ability to function as the disappearing or subliminal persuader, although that seems to contradict their spectacularity as just argued. The public regards them as belonging to the regimes of advertising and publicity, as types of cultural paratexts that refer to primary texts-either the film or the candidate. Thus, they are not essential to their referents, so we need not pay attention to them in order to fulfill our duties as consumers. We may even be aware that the two possess persuasive functions but remain oblivious as to how they specifically manipulate us to adopt certain positions. Of course, the public need not agree with the message behind the product being sold, or with the general vehicle for promotion; however, we could here invoke the well-worn advertising

\footnotetext{
${ }^{26}$ Richard Dyer, Heavenly Bodies: Film_Stars and Society, $2^{\text {nd }}$ ed. (New York: Routledge, 2004), 15-16.

${ }^{27}$ Hamish Pringle, Celebrity Sells (Chichester, UK: Wiley, 2004), xxii.
} 
adage that there is no such thing as bad publicity.

Needless to say, the four articles of this special issue and, indeed, the topics indicated above do not exhaust the possibilities for the study of campaign music. By limiting ourselves to the presidential campaign, this research collective has focused on the exceptional case, yet one of such significance that it naturally initiates this pioneering research into the sounds of (American) elections. Still, the concurrent competitions for Senate offices, seats in the House of Representatives, gubernatorial mansions, and any number of local posts also play out with musical underscores, which make for interesting and valuable comparators for those at the presidential level as well as research topics in and of themselves. Fine-grained studies are needed to investigate the social relationships surrounding presidential campaign music, such as, for example, specific celebrity alliances with candidates or the musical responses of particular communities to candidates.

Some work has already been undertaken in these areas. Focusing on music and politics more broadly, John Street explores the reasons and the circumstances behind the political engagement of musicians. Rather than emphasizing the perceived correlation between cultural and social change and music's content, Street advocates focusing on musicians' biographies and their ability to transform fame into political communication. Street also investigates the ways in which politicians appropriate celebrity rhetoric in the quest to fashion their own public personas. ${ }^{28}$ Turning to 2008 , the unprecedented number of musical responses to Obama's first campaign provided fertile ground for scholars in the area of hip-hop. Travis L. Gosa, Erik Nielson, Lester K. Spence, Murray Forman, and several others deploy various methodological approaches to investigate Obama-themed songs and mixtapes, the online and offline activities of black youth, the civic engagement of hip-hop organizations, and more broadly, hip-hop's role in twenty-first-century politics. ${ }^{29}$ Focusing on YouTube, Carol Vernallis analyzes the viral media that emerged during the 2008 campaign, including the "Yes We Can" and "Barack RickRoll'd" videos. ${ }^{30}$ Through the concept of collage as a critical lens, Richard Daniel Blim addresses campaign advertising and

\footnotetext{
${ }^{28}$ John Street, “The Pop Star as Politician: From Belafonte to Bono, from Creativity to Conscience," in The Resisting Muse: Popular Music and Social Protest, ed. Ian Peddie (Burlington, VT: Ashgate, 2006), 49-64; "Celebrity Politicians: Popular Culture and Political Representation," British Fournal of Politics and International Relations 6, no. 4 (2004): 435-52; Music and Politics (Cambridge: Polity, 2012); and John Street, Seth Hague, and Heather Savigny, "Playing to the Crowd: The Role of Music and Musicians in Political Participation," British Fournal of Politics E International Relations 10, no. 2 (2008): 269-85. ${ }^{29}$ Travis L. Gosa, "Not Another Remix: How Obama Became the First Hip-Hop President," Fournal of Popular Music Studies 22, no. 4 (2010): 389-415; and “The Audacity of Dope': Rap Music, Race, and the Obama Presidency," in The Iconic Obama, 2007-2009: Essays on Media Representations of the Candidate and New President, ed. Nicholas A. Yanes and Derrais Carter (Jefferson, NC: McFarland, 2012), 85-96; Erik Nielson, “'My President is Black, My Lambo's Blue': The Obamafication of Rap?" Fournal of Popular Music Studies 21, no. 4 (2009): 344-63; Murray Forman, "Conscious Hip-Hop, Change, and the Obama Era," American Studies Fournal 54 (2010), http://www.asjournal.org/54-2010/conscious-hip-hop/; Lester K. Spence, "Obama and the Future of Hip-hop Politics," in Stare in the Darkness: The Limits of Hip-hop and Black Politics (Minneapolis: University of Minnesota Press, 2011), 157-76. See also Michael P. Jeffries, “Obama as Hip-Hop Icon,” epilogue to Thug Life: Race, Gender, and the Meaning of Hip-Hop (Chicago: University of Chicago Press, 2011), 199-206; H. Samy Alim and Geneva Smitherman, “'My President's Black, My Lambo's Blue': Hip Hop, Race, and the Culture Wars,” in Articulate While Black: Barack Obama, Language, and Race in the U.S. (Oxford: Oxford University Press, 2012), 130-66; Shaun Ossei-Owusu, “'Barack Obama's Anomalous Relationship with the Hip-Hop Community," in The Obama Phenomenon: Toward a Multiracial

Democracy, ed. Charles P. Henry, Robert L. Allen, and Robert Chrisman (Urbana: University of Illinois Press, 2011), 218-35; and Sanford K. Richmond, "Paint The White House Black!! A Critical Discourse Analysis Look at Hip Hop's Social, Cultural, and Political Influence on the Presidency of Barack Obama," Western Fournal of Black Studies 37, no. 4 (Winter 2013): 249-57. Two forthcoming volumes, The Hip Hop E Obama Reader (New York: Oxford University Press, 2015) edited by Gosa and Nielson, and Hip-Hop Activism in the Obama Era (Chicago: Third World Press, 2015) by Bakari Kitwana will also address this topic.

${ }^{30}$ Carol Vernallis, "Audiovisual Change: Viral Web Media and the Obama Campaign." In Unruly Media: YouTube, Music Video, and the New Digital Cinema (New York: Oxford University Press, 2013), 155-80.
} 
the candidate's iPod as well as Obama-themed mashups and hip-hop offerings. ${ }^{31}$ Finally, David R. Dewberry and Jonathan H. Millen investigate how candidates utilize music rhetorically in various campaign contexts. ${ }^{32}$

Future research would also situate the campaign-music practices in the United States in relation to those of other countries to ascertain (among other things): (1) what the local and national traditions are for campaign music, (2) the extent to which the American model has influenced practices elsewhere, and (3) the role of media-especially social media—in the production and dissemination of campaign music and its discourses. ${ }^{33}$ Moreover, the songs for election campaigns reflect a history that warrants closer study, especially when one considers the amount of popular literature that the topic has generated: beneath the surface of parody and quotation resides a layer of meaning production that attempts to brand the candidate and hook the voter, in a complex process of identification and mobilization. ${ }^{34}$ And the field is wide open, on the one hand, for consulting with production companies regarding the construction of target audiences for campaign music and, on the other, for exploring its effects through cognitive approaches, as applied experimentally to voters. ${ }^{35}$

Ultimately, the 2012 campaign soundscape serves as a lens through which we might interrogate the ever shifting (or dissolving) boundaries between the live and the recorded, public and private, real and virtual, artist and audience, and the popular and the political as well as the manner in which these binaries both shape and challenge electoral politics. Such research, moreover, sheds light on the processes of music creation, distribution, and consumption as well as the meanings voters attach to such acts in the age of media convergence. We genuinely hope that our work here will instigate a meaningful dialogue about campaign soundscapes as we move into the next election cycle.

\footnotetext{
${ }^{31}$ Richard Daniel Blim, “The Electoral Collage: Mapping Barack Obama’s Mediated Identities in the 2008 Election,” in "Patchwork Nation: Collage, Music, and American Identity" (PhD diss., University of Michigan, 2013), 364-453. See also Matthew F. Jordan, “Obama's iPod: Popular Music and the Perils of Postpolitical Populism,” Popular Communication: The International fournal of Media and Culture 11, no. 2 (2013): 99-115.

${ }^{32}$ David R. Dewberry and Jonathan H. Millen, "Music as Rhetoric: Popular Music in Presidential Campaigns," Atlantic Fournal of Communication 22 no. 2 (March 2014): 81-92; and "Music as Rhetoric: Music in the 2012 Presidential Campaign," in Studies of Communication in the 2012 Presidential Campaign, ed. Robert E. Denton Jr. (Lanham, MD: Lexington, 2014), 17594.

${ }^{33}$ See, for example, Jan Maghinay Padios, "Can You Hear Us Now? Ringtones and Politics in the Contemporary Philippines," in The Oxford Handbook of Mobile Music Studies, ed. Sumanth S. Gopinath and Jason Stanyek (Oxford: Oxford University Press, 2014), 359-381.

${ }^{34}$ Some bibliographic work has been done in this area. See William Miles, Songs, Odes, Glees, and Ballads: A Bibliography of American Presidential Campaign Songsters (New York: Greenwood, 1990); Danny O. Crew, Presidential Sheet Music: An Illustrated Catalogue of Published Music Associated with the American Presidency and Those who Sought the Office (Jefferson, NC: McFarland, 2001); and American Political Music: A State-by-State Catalog of Printed and Recorded Music Related to Local, State and National Politics, 1756-2004, 2 vols. (Jefferson, NC: McFarland, 2005).

${ }^{35}$ Several researchers have explored the affective dimensions of political media. It might be useful to apply their methodological frameworks to the study of music. See Drew Westen, The Political Brain: The Role of Emotion in Deciding the Fate of the Nation (New York: PublicAffairs, 2007); George Lakoff, The Political Mind: Why You Can't Understand 21st-Century Politics with an 18th-Century Brain (New York: Viking, 2008); and George E. Marcus, W. Russell Neuman, and Michael MacKuen, eds. The Affect Effect: Dynamics of Emotion in Political Thinking and Behavior (Chicago: University of Chicago Press, 2007).
} 


\section{References}

Alim, H. Samy, and Geneva Smitherman. “'My President's Black, My Lambo's Blue': Hip Hop, Race, and the Culture Wars." In Articulate While Black: Barack Obama, Language, and Race in the U.S., 130-66. Oxford: Oxford University Press, 2012.

Blim, Richard Daniel. "Patchwork Nation: Collage, Music, and American Identity." PhD diss., University of Michigan, 2013. See esp. chap. 5, "The Electoral Collage: Mapping Barack Obama's Mediated Identities in the 2008 Election," 364-453.

Clayton, Dewey M. The Presidential Campaign of Barack Obama: A Critical Analysis of a Racially Transcendent Strategy. New York: Routledge, 2010.

Crew, Danny O. American Political Music: A State-by-State Catalog of Printed and Recorded Music Related to Local, State and National Politics, 1756-2004. 2 vols. Jefferson, NC: McFarland, 2005.

- Presidential Sheet Music: An Illustrated Catalogue of Published Music Associated with the American Presidency and Those Who Sought the Office. Jefferson, NC: McFarland, 2001.

Debord, Guy. La Société du spectacle. Paris: Buchet-Chastel, 1967.

Dewberry, David R., and Jonathan H. Millen. "Music as Rhetoric: Music in the 2012 Presidential Campaign." In Studies of Communication in the 2012 Presidential Campaign, edited by Robert E. Denton Jr., 175-94. Lanham, MD: Lexington, 2014.

—_. "Music as Rhetoric: Popular Music in Presidential Campaigns." Atlantic Journal of Communication 22 no. 2 (March 2014): 81-92, http://dx.doi.org/10.1080/15456870.2014.890101.

Dyer, Richard. Heavenly Bodies: Film Stars and Society. 2nd ed. New York: Routledge, 2004.

Forman, Murray. "Conscious Hip-Hop, Change, and the Obama Era.” American Studies Journal 54 (2010). http://www.asjournal.org/54-2010/conscious-hip-hop.

Genette, Gérard. Seuils. Paris: Éditions du Seuil, 1987.

Gosa, Travis L. “'The Audacity of Dope': Rap Music, Race, and the Obama Presidency.” In The Iconic Obama, 2007-2009: Essays on Media Representations of the Candidate and New President, edited by Nicholas A. Yanes and Derrais Carter, 85-96. Jefferson, NC: McFarland, 2012.

- "Not Another Remix: How Obama Became the First Hip-Hop President." Journal of Popular Music Studies 22, no. 4 (2010): 389-415, http://dx.doi.org/10.1111/j.1533-1598.2010.01252.x.

Jeffries, Michael P. "Obama as Hip-Hop Icon." Epilogue to Thug Life: Race, Gender, and the Meaning of HipHop, 199-206. Chicago: University of Chicago Press, 2011.

Jenkins, Henry. “Convergence? I Diverge.” Technology Review 104, no. 5 (2001): 93.

Jones, Jeffrey P. "Presidential Campaigns as Cultural Events: The Convergence of Politics and Popular Culture in Election 2012.” In The 2012 Presidential Campaign: A Communication Perspective, edited by Robert E. Denton Jr., 115-31. Lanham, MD: Rowman \& Littlefield, 2013.

_ _ "Parody, Performativity, and Play: The Reinvigoration of Citizenship through Political Satire." In A Companion to New Media Dynamics, edited by John Hartley, Jean Burgess and Axel Bruns, 396-406. Malden, MA: Wiley-Blackwell, 2013. http://dx.doi.org/10.1002/9781118321607.

Jordan, Matthew F. "Obama's iPod: Popular Music and the Perils of Postpolitical Populism." Popular Communication: The International Journal of Media and Culture 11, no. 2 (2013): 99-115.

Kellner, Douglas. "Barack Obama and Celebrity Spectacle." International Journal of Communication 3 (2009): 715-41.

Kernan, Lisa. Coming Attractions: Reading American Movie Trailers. Austin: University of Texas Press, 2004. 
Lakoff, George. The Political Mind: Why You Can't Understand 21st-Century Politics with an 18th-Century Brain. New York: Viking, 2008.

Larson, Jodi. "American Tune: Postwar Campaign Songs in a Changing Nation." Journal of Popular Culture 42, no. 1 (2009): 3-26, http://dx.doi.org/10.1111/j.1540-5931.2009.00568.x.

Marcus, George E., W. Russell Neuman, and Michael MacKuen, eds. The Affect Effect: Dynamics of Emotion in Political Thinking and Behavior. Chicago: University of Chicago Press, 2007. http://dx.doi.org/10.7208/chicago/9780226574431.001.0001.

Miles, William. Songs, Odes, Glees, and Ballads: A Bibliography of American Presidential Campaign Songsters. New York: Greenwood, 1990.

New York Times. "Film Flashes.” June 3, 1917.

Nicoll, Janet I., and G. Douglas Nicoll. "Political Campaign Songs from Tippecanoe to '72." Popular Music and Society 1, no. 4 (Summer 1972): 193-209, http://dx.doi.org/10.1080/03007767208590992.

Nielson, Erik. "How Hip-Hop Fell Out of Love with Obama.” Guardian, August 23, 2012. . "'My President is Black, My Lambo's Blue': The Obamafication of Rap?” Journal of Popular Music Studies 21, no. 4 (2009): 344-63, http://dx.doi.org/10.1111/j.1533-1598.2009.01207.x.

“Obamas Praise Stevie Wonder at White House.” CNN, February 26, 2009. http://www.cnn.com/2009/SHOWBIZ/Music/02/26/stevie.wonder.obama.

Ossei-Owusu, Shaun. "Barack Obama's Anomalous Relationship with the Hip-Hop Community." In The Obama Phenomenon: Toward a Multiracial Democracy, edited by Charles P. Henry, Robert L. Allen, and Robert Chrisman, 218-35. Urbana: University of Illinois Press, 2011.

Padios, Jan Maghinay. "Can You Hear Us Now? Ringtones and Politics in the Contemporary Philippines." In The Oxford Handbook of Mobile Music Studies, edited by Sumanth S. Gopinath and Jason Stanyek, 359-381. Oxford: Oxford University Press, 2014.

Parry-Giles, Trevor, and Shawn J. Parry-Giles. "Political Scopophilia, Presidential Campaigning, and the Intimacy of American Politics." Communication Studies 47, no. 3 (1996): 191-205, http://dx.doi.org/10.1080/10510979609368475.

Pringle, Hamish. Celebrity Sells. Chichester, UK: Wiley, 2004.

Richmond, Sanford K. "Paint The White House Black!! A Critical Discourse Analysis Look at Hip Hop's Social, Cultural, and Political Influence on the Presidency of Barack Obama." Western Journal of Black Studies 37, no. 4 (Winter 2013): 249-57.

Schoening, Benjamin S., and Eric T. Kasper. Don't Stop Thinking about the Music: The Politics of Songs and Musicians in Presidential Campaigns. Lanham, MD: Lexington, 2012.

Silber, Irwin. Songs America Voted By: With the Words and Music That Won and Lost Elections and Influenced the Democratic Process. Harrisburg, PA: Stackpole, 1971.

Sinnreich, Aram. Mashed Up: Music, Technology, and the Rise of Configurable Culture. Amherst: University of Massachusetts Press, 2010.

Spence, Lester K. "Obama and the Future of Hip-hop Politics." In Stare in the Darkness: The Limits of Hiphop and Black Politics, 157-76. Minneapolis: University of Minnesota Press, 2011. http://dx.doi.org/10.5749/minnesota/9780816669875.003.0006.

Street, John. "Celebrity Politicians: Popular Culture and Political Representation." British Journal of Politics and International Relations 6, no. 4 (November 2004): 435-52, http://dx.doi.org/10.1111/j.1467856X.2004.00149.x. 
. Music E Politics. Cambridge, UK: Polity, 2012.

. "The Pop Star as Politician: From Belafonte to Bono, from Creativity to Conscience." In The Resisting Muse: Popular Music and Social Protest, edited by Ian Peddie, 49-64. Burlington, VT: Ashgate, 2006.

Street, John, Seth Hague, and Heather Savigny. "Playing to the Crowd: The Role of Music and Musicians in Political Participation." British Journal of Politics E International Relations 10, no. 2 (2008): 269-85, http://dx.doi.org/10.1111/j.1467-856X.2007.00299.x.

Vernallis, Carol. "Audiovisual Change: Viral Web Media and the Obama Campaign.” In Unruly Media: YouTube, Music Video, and the New Digital Cinema, 155-80. New York: Oxford University Press, 2013. http://dx.doi.org/10.1093/acprof:oso/9780199766994.001.0001.

Wenner, Jann S. “A Conversation With Barack Obama.” Rolling Stone, July 10-24, 2008. http://www.jannswenner.com/Archives/Barack_Obama.aspx.

Westen, Drew. The Political Brain: The Role of Emotion in Deciding the Fate of the Nation. New York: PublicAffairs, 2007.

White House Office of the Press Secretary. "Remarks by the President at a Campaign Event in Roanoke, Virginia." News release, July 13, 2012. http://www.whitehouse.gov/the-pressoffice/2012/07/13/remarks-president-campaign-event-roanoke-virginia.

"Why Are They Called 'Trailers' If They're Shown Before the Movie?" The Straight Dope (blog), November 6, 2007. http://www.straightdope.com/columns/read/2270/why-are-they-called-trailers-if-theyreshown-em-before-em-the-movie.

Yanes, Nicholas A., and Derrais Carter, eds. The Iconic Obama, 2007-2009: Essays on Media Representations of the Candidate and New President. Jefferson, NC: McFarland, 2012.

Young, Dannagal G., R. Lance Holbert, and Kathleen Hall Jamieson. "Successful Practices for the Strategic Use of Political Parody and Satire: Lessons From the P6 Symposium and the 2012 Election Campaign.” American Behavioral Scientist 58, no. 9 (2014): 1111-30, http://dx.doi.org/10.1177/0002764213506213. 